\title{
Ketahanan Pangan Rumah Tangga di Kecamatan Jaro Kabupaten Tabalong, Kalimantan Selatan
}

\section{(House Hold Food Security in Jaro District Tabalong Regency, South Kalimantan)}

\author{
Ahmad Suhaimi \\ Program Studi Agribisnis, Sekolah Tinggi Ilmu Pertanian Amuntai \\ Ahmad99ec@gmail.com
}

\begin{abstract}
ABSTRAK
Penelitian ini dilakukan dengan tujuan untuk mengkaji ketahanan pangan rumah tangga, menganalisis faktor-faktor sosial dan ekonomi yang mempengaruhi ketahanan pangan rumah tangga, serta menentukan faktor-faktor sosial dan ekonomi yang paling dominan dalam ketahanan pangan di Kecamatan Jaro Kabupaten Tabalong. Tingkat ketahanan pangan rumah tangga didominasi oleh kelompok pangan yang cukup yaitu 30 rumah tangga atau 40\% dan ketahanan pangan 29 rumah tangga dengan menghadirkan 38,67\%. Kelompok yang tidak memiliki ketahanan pangan adalah 16 rumah tangga atau 21,33\%. Kelompok rumah tangga memiliki persediaan beras yang aman pangan antara 120-239 hari dengan frekuensi makan anggota rumah tangga 3 kali sehari. Hasil analisis uji F diperoleh nilai 2,431> nilai $F$ tabel sebesar 2,346 pada odds 0,05 <0,05 berarti bahwa semua variabel dalam persamaan secara simultan berpengaruh signifikan terhadap ketahanan pangan rumah tangga. Hasil analisis uji t faktor sosial ekonomi yang paling dominan pengaruhnya terhadap ketahanan pangan rumah tangga adalah nilai faktor pendapatan sebesar 2,058 t hitung $>$ t tabel nilai 1,667 dengan peluang 0,041 <0,05. Hal ini menunjukkan bahwa faktor pendapatan berpengaruh signifikan, tetapi jumlah keluarga, tingkat pendidikan keluarga, dan pengeluaran, masing-masing tidak berpengaruh signifikan terhadap ketahanan pangan rumah tangga.
\end{abstract}

Kata kunci: Ketahanan, pangan, rumah, tangga, faktor.

\section{ABSTRACT}

This study aims to assess household food security, social and economicsfactors that affect household food security and knowing the dominant factor in household food security in the village of Namun, Jaro District of Tabalong regency. The level of household food security is dominated by a group of food enough that 30 households or by $40 \%$ and 29 household food security by presenting 38.67\%. Groups that are not food secure are 16 households or $21.33 \%$. Groups of households have food secure rice supplies between 120-239 days with eating frequency of household members 3 times a day. F test analysis results obtained value of 2.431> F table value of 2.346 at odds of $0.05<0.05$ means that all the variables in the equation simultaneously a significant effect on household food security. Results of t test analysis of socioeconomics factors are the most dominant influence on household food security is a factor value income amounted to $2.058 t$ count> $t$ table value of 1.667 with 0.041 odds $<0.05$. This suggests that factors ofincomesignificantly affect, but the number of family, the level of family Education, and expenditure, each no significant effect on household food security.

Key words: Resilience, food, home, stairs, factors.

\section{PENDAHULUAN}

Pangan merupakan sumber kalori, protein, mineral dan vitamin untuk memenuhi kebutuhan gizi. Pangan lebih jauh menjadi bagian yang sangat penting dalam kehidupan bernegara khususnya dalam sektor strategis perekonomian dan keamanan, karena sektor pangan merupakan industri masal yang melibatkan banyak orang mulai bidang produksi, pengolahan, distribusi, konsumsi dan sistem pendukung lainnya. Beras merupakan bahan makanan pokok sebagian besar penduduk Indonesia. Seiring dengan bertambahnya jumlah penduduk kebutuhan beras pun meningkat.

Kecamatan Jaro berada pada wilayah Kabupaten Tabalong Provinsi Kalimantan Selatan. Pekerjaan masyarakat lebih dominan 
sebagai petani padi dan berkebun karet. Ketahanan pangan rumah tangga petani tentunya sangat dipengaruhi oleh kondisi sosial dan ekonomi masyarakat.

Penelitian ini dilakukan dengan tujuan untuk mengkaji ketahanan pangan rumah tangga, menganalisis faktor-faktor sosial dan ekonomi yang mempengaruhi ketahanan pangan rumah tangga, serta menentukan faktor-faktor sosial dan ekonomi yang paling dominan dalam ketahanan pangan di Kecamatan Jaro Kabupaten Tabalong.

\section{METODE PENELITIAN}

\section{Metoda dan Desain Penelitian}

Penelitian ini menggunakan metoda deskriptif kuantitatif dengan teknik observasi partisipasi, dan mengacu pada desain penelitian korelasional.

\section{Tempat dan Waktu Penelitian}

Penelitian ini dilaksanakan di wilayah Desa Namun Kecamatan Jaro Kabupaten Tabalong, Provinsi Kalimantan Selatan. Waktu penelitian dimulai dari bulan Januari Mei 2015.

\section{Jenis dan Sumber Data}

Data yang dikumpulkan dalam penelitian terdiri dari data primer dan data sekunder. Data primer dari wawancara langsung dengan masyarakat atau keluarga tani yang ada di desa tersebut dengan menggunakan daftar pertanyaan yang telah disiapkan sebelumnya, yaitu yang berkaitan dengan semua kegiatan dalam penelitian ini. Data sekunder diperoleh dari instansiinstansi terkait serta melalui studi pustaka dari berbagai media yang berhubungan dengan penelitian ini seperti data produksi

\section{HASIL DAN PEMBAHASAN}

\section{Faktor-faktor Sosial dan Ekonomi}

padi, jumlah penduduk atau jumlah keluarga tani.

\section{Metode Pengumpulan Data}

Pengambilan sampel pada penelitian ini dilakukan dengan metoda purposive sampling terhadap rumah tangga. Responden dipilih secara sengaja berdasarkan kesediaan untuk diwawancarai dengan penekanan pada kekayaan informasi yang dimiliki dan relevansinya dengan tujuan kajian. Untuk memenuhi kriteria tersebut maka yang menjadi responden adalah ibu rumah tangga.Jumlah sampel yang diambil menggunakan rumus Slovin :

$$
\mathrm{n}=\frac{N}{1+N \cdot e}^{2}
$$

Desa Namun di Kecamatan Jaro mempunyai 300 kepala keluarga, maka diperoleh 75 responden.

\section{Analisis Data}

1. Ketahanan pangan rumah tangga dapat dilakukan dengan menghitung ketersedian pangan/ beras pada rumah tangga. Kategori ketersedian pangan/ beras adalah sebagai berikut:

Tidak Tahan Pangan $=1-119$ Hari

Cukup Tahan Pangan $=120-239$ Hari

Tahan Pangan $=>240$ Hari

2. Faktor-faktor sosial dan ekonomi yang mempengaruhi ketahanan pangan rumah tanggadianalisis dengan model regresi linear berganda paket program The Statistical Product and Service (SPPS) versi 21.

3. Penentuan faktor-foktor sosial dan ekonomi yang dominan mempengaruhi ketahanan rumah tangga dilakukan dengan uji t secara parsial.

\section{a. Jumlah Anggota Rumah Tangga}

Rata-rata jumlah anggota rumah tangga di wilayah penelitian dapat dilihat pada Tabel 1 dibawah ini.

Tabel 1. Jumlah anggota rumah tangga 


\begin{tabular}{cccc}
\hline \multicolumn{5}{l}{ Ahmad Suhaimi, Ketahanan pangan rumah tangga... } \\
\hline \multirow{4}{*}{ No } & $\begin{array}{c}\text { Tingkat Jumlah Anggota } \\
\text { Rumah Tangga }\end{array}$ & $\begin{array}{c}\text { Jumlah Kepala } \\
\text { Keluarga }\end{array}$ & Persentasi (\%) \\
\hline 1. & $0-1$ & 12 & 16,00 \\
2. & $2-3$ & 23 & 30,67 \\
3. & $4-5$ & 30 & 40,00 \\
4. & $>6$ & 10 & 13,33 \\
\hline Jumlah & & 75 & 100 \\
\hline
\end{tabular}

Kelompok anggota jumlah rumah tangga terbesar yaitu 30 kepala keluarga atau sebesar 40,00\% dari seluruh jumlah rumah tangga responden, sedangkan kelompok jumlah anggota rumah tangga $>6$ orang merupakan kelompok terkecil yaitu 10 kepala keluarga

\section{b. Tingkat Pendidikan Kepala Keluarga}

Rata-rata tingkat pendidikan kepala keluarga di wilayah penelitian dapat dilihat pada Tabel 2. atau $13,33 \%$ dari seluruh jumlah responden.

Tabel 2. Tingkat pendidikan kepala keluarga di desa

\begin{tabular}{cccc}
\hline \multirow{2}{*}{ No } & Tingkat Pendidikan & $\begin{array}{c}\text { Jumlah Kepala } \\
\text { Keluarga }\end{array}$ & Persentasi ( \% ) \\
\hline 1. & Tidak Tamat SD & 6 & 8,00 \\
2. & Tamat SD / Sederajat & 38 & 50,67 \\
3. & Tamat SLTP / Sederajat & 23 & 30,67 \\
4. & Tamat SLTA / Sederajat & 8 & 10,66 \\
\hline Jumlah & & 75 & 100 \\
\hline
\end{tabular}

Tingkat pendidikan kepala keluarga yang tamat Sekolah Dasar adalah kelompok terbesar yaitu sebanyak 38 orang atau $50,67 \%$, sedangkan tidak tamat SD berada pada kelompok terkecil yaitu sebayak 6 orang atau $8,00 \%$.

\section{c. Pendapatan Rumah Tangga}

Rata-rata pendapatan rumah tangga di wilayah penelitian dapatdilihat pada Tabel 3 .

Tabel 3. Jumlah rata-rata pendapatan rumah tangga di desa

\begin{tabular}{cccc}
\hline No & $\begin{array}{c}\text { Tingkat Pendapatan } \\
\text { Rumah Tangga } \\
(\mathrm{Rp})\end{array}$ & $\begin{array}{c}\text { Jumlah Kepala } \\
\text { Keluarga }\end{array}$ & Persentasi $(\%)$ \\
\hline 1. & $0-1.500 .000$ & 33 & 44,00 \\
2. & $1.500 .001-2.500 .000$ & 29 & 38,67 \\
3. & $2.500 .001-3.500 .000$ & 9 & 12,00 \\
4. & $3.500 .001-4.500 .000$ & 4 & 5,33 \\
\hline Jumlah & & 75 & 100 \\
\hline
\end{tabular}

Jumlah pendapatan rumah tangga terbesar berada pada kisaran Rp 3.500.001 4.500.000 atau 5,33\%, sedangkan pendapatan terendah menduduki peringkat pertama yaitu sebanyak 33 kepala keluarga dengan persentasi $44,00 \%$.

\section{d. Pengeluaran Rumah Tangga}

Rata-rata pengeluaran rumah tangga responden dapatdilihat pada Tabel 4. 
Tabel 4. Jumlah rata-rata pengeluaran rumah tangga di desa

\begin{tabular}{cccc}
\hline No & $\begin{array}{c}\text { Tingkat Pengeluaran } \\
\text { Rumah Tangga } \\
(\mathrm{Rp})\end{array}$ & $\begin{array}{c}\text { Jumlah Kepala } \\
\text { Keluarga }\end{array}$ & Persentasi (\%) \\
\hline 1. & $0-750.000$ & 15 & 20,00 \\
2. & $750.001-1.500 .000$ & 49 & 65,33 \\
3. & $1.500 .001-2.250 .000$ & 9 & 12,00 \\
4. & $2.250 .001-3.000 .000$ & 2 & 2,67 \\
\hline Jumlah & & 75 & 100 \\
\hline
\end{tabular}

Jumlah pengeluaran rumah tangga terbesar berada pada kisaran $\mathrm{Rp} 2.250 .001$ 3.000 .000 atau hanya $2,67 \%$, sedangkan

\section{Ketahanan Pangan Rumah Tangga}

Ketahanan pangan rumah tangga berkaitan dengan ketersedian pangan dalam rumah tangga tani dalam waktu satu tahun. Untuk mengetahui ketahanan pangan rumah kelompok terbesar berada pada jumlah pengeluaran antara Rp. $750.001-2.250 .000$ dengan presentasi $65,33 \%$.

tangga dapat dilihat berdasarkan hasil analisis ketersediaan pangan pokok rumah tangga dalam hal ini adalah ketersediaan beras, seperti terlihat pada Tabel 5 di bawah ini.

Tabel 5. Rata-rata ketahanan pangan rumah tangga desa

\begin{tabular}{ccrr}
\hline No & $\begin{array}{c}\text { Tingkat Ketahanan Pangan } \\
\text { Rumah Tangga } \\
\text { (Hari) }\end{array}$ & Jumlah KK & Persentasi (\%) \\
\hline 1. Tidak Tahan Pangan (1- 119 Hari) & 16 & 21,33 \\
2. $\quad$ Cukup Tahan Pangan (120-239 Hari) & 30 & 40,00 \\
3. Tahan Pangan (>240 Hari ) & 29 & 38,67 \\
\hline Jumlah & 75 & 100 \\
\hline
\end{tabular}

Tingkat ketahanan pangan rumah tangga yang paling banyak merupakan kelompok cukup pangan yaitu 30 kepala keluarga atau sebesar 40,00 \% dan tahan pangan 29 kepala keluarga dengan presentasi $38,67 \%$. Kelompok yang tidak tahan pangan berjumlah 16 kepala keluarga atau 21,33\%.

Data di atas menjelaskan bahwa ketahanan pangan rumah tangga di Desa Namun didominasi oleh kelompok dalam katagori cukup tahan pangan karena persedian beras pada rumah tangga Desa Namun antara 120 - 239 hari dengan frekuensi makan 3 kali sehari. Menurut Suharjo (1985), ketersediaan pangan dalam rumah tangga atau daerah yang mengacu pada pangan yang cukup dan tersedia dalam jumlah yang dapat memenuhi kebutuhan konsumsi tangga atau individu. Penentuan jangka waktu ketersedian makanan pokok di daerah biasanya dilihat dengan mempertimbangkan jarak antara musim tanam dengan musin tanam berikutnya.

Sesuai pendapat Hendayana dan Dewi (2005), ketahanan pangan pada rumah tangga miskin, erat hubungannya dengan karakteristik rumah tangga itu sendiri, yakni rendahnya pemilikan sumberdaya lahan dan asset lainnya, kualitas sumberdaya manusia (pendidikan formal) di rumah tangga relatif rendah, akses terhadap sumber modal tidak ada, dan akses terhadap sumber informasi terkendala. Sebagian besar rumah tangga $(69,9 \%)$ hanya mengandalkan pendapatan dari hasil buruh (tani dan luar tani) yang tidak dapat diprediksi besarannya, sehingga mempengaruhi ketersediaan pangan, baik dalam jumlah apalagi kualitasnya, sementara itu petani sering tidak memiliki cadangan pangan (stok) yang cukup.

Ketahanan pangan di Desa Namun Kecamatan Jaro Kabupaten Tabalong 
termasuk dalam katagori cukup tahan pangan karena rumah tangga yang ada di Desa Namun dapat memenuhi kebutuhan pangan dari usaha taninya sendiri.

\section{Pengaruh Faktor Faktor Sosial Ekonomi terhadap Ketahanan Pangan Rumah Tangga}

Tabel 6. Faktor-faktor sosial dan ekonomi terhadap ketahanan pangan rumah tangga

\begin{tabular}{llrrrr}
\hline No & \multicolumn{1}{c}{ Variabel } & $\begin{array}{c}\text { Koefisien } \\
\text { regresi }\end{array}$ & t-hitung & Peluang & VIF \\
\hline 1 & Konstanta & 3,610 & 0,865 & $0,390^{\mathrm{ns}}$ & \\
2 & Jumlah Keluarga & 0,138 & 0,594 & $0,555^{\mathrm{ns}}$ & 1.012 \\
3 & Tingkat Pendidikan KK & 0,260 & 1,475 & $0,145^{\mathrm{ns}}$ & 1.033 \\
4 & Pendapatan & 0,367 & 2,085 & $0,041^{*}$ & 1.192 \\
5 & Pengeluaran & 0,121 & 0,521 & $0,604^{\mathrm{ns}}$ & 1.226 \\
\hline
\end{tabular}

Keterangan :

Ns = peluang $>0,05$ (tidak berpengaruh bermakna)

$*=$ peluang $<0,05$ (berpengaruh bermakna)

Dengan demikian dapatlah disusun model persamaan regresi sebagai berikut: $Y=3,610+0,138 X_{1}+0,260 X_{2}+0,367 X_{3}+0,121 X_{4}$

Dimana :

$$
\begin{aligned}
& \mathrm{Y}=\text { Ketahanan pangan rumah tangga } \\
& \mathrm{X}_{1}=\text { Ukuran keluarga } \\
& \mathrm{X}_{2}=\text { Tingkat pendidikan kepala keluarga } \\
& \mathrm{X}_{3}=\text { Pendapatan } \\
& \mathrm{X}_{4}=\text { Pengeluaran }
\end{aligned}
$$

Persamaan diatas menunjukkan bahwa setiap terjadi penambahan jumlah keluarga sebesar $1 \%$ akan menambah ketahanan pangan rumah tangga sebesar 0,138 dan setiap penambahan tingkat pendidikan kepala keluarga sebesar $1 \%$ akan menambah ketahanan pangan rumah tangga sebesar 0,260, lalu setiap penambahan Pendapatan sebesar $1 \%$ akan menambah sebesar 0,367 , kemudian setiap penambahan pengeluaran sebesar 1\% akan menambah ketahanan pangan rumah tangga sebesar 0,121 .

Koefisien determinasi $\left(\mathrm{R}^{2}\right)$ dari model regrisi tersebut adalah 0,122. Hal ini menunjukkan bahwa variabel yang dapat dijelaskan oleh faktor sosial dan ekonomi dalam model tersebut masing-masing adalah $12,2 \%$, sedangkan yang tidak diterangkan
Hasil analisis regresi berganda pengaruh faktor-faktor sosial dan ekonomi terhadap ketahanan rumah tangga disajikan pada Tabel 6 berikut. 
berpengaruh bermakna terhadap ketahanan pangan rumah tangga di Desa Namun Kecamatan Jaro Kabupaten Tabalong.

\section{KESIMPULAN}

Ketahanan pangan rumah tangga di Desa Namun Kecamatan Jaro Kabupaten Tabalong termasuk dalam katagori cukup tahan pangan dengan persedian pangan (beras) antara 120 - 239 hari dengan tiga kali makan sehari. Hasil analisis Uji t, faktorfaktor yang dominan mempengaruhi ketahanan pangan rumah tangga adalah faktor pendapatan nilai t-hitung sebesar $2,058>$ nilai t tabel 1,667 dengan peluang $0,041<0,05$. Sedangkan faktor jumlah keluarga, tingkat pendidikan kepala keluarga dan pengeluaran masing-masing tidak dipengaruhi bermakna.

\section{DAFTAR PUSTAKA}

Hendayana, R. \& Y.A. Dewi. 2005. Anatomi Ketahanan Pangan Pada Rumah Tangga Miskin Dan Implikasinya Terhadap Kebijakan Inovasi Pertanian. Jurnal Balai Besar Pengkajian dan Pengembangan Teknologi Pertanian.

Soemarno, 2012. Kompendium Kajian Lingkungan dan Pembangunan "Ketahanan Pangan”. PPSUB Malang.

Suhardjo. 2003. Perencanaan Pangan dan Gizi. Bumi Aksara Bekerja sama dengan Pusat Antar Universitas-Pangan dan Gizi Institut Pertanian Bogor. Jakarta.

Suliyanto. 2011. Ekonometrika Terapan: Teori \& Aplikasi dengan SPSS. CV. Andi Offset. Yogyakarta. 